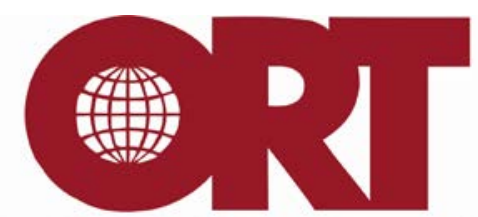

UNIVERSIDAD ORT
Uruguay

\title{
Peer effects in risk aversion
}

\author{
Balsa, Ana I. \\ Universidad de Montevideo \\ Gandelman, Néstor \\ Universidad ORT Uruguay \\ González, Nicolás \\ Centro de Estudios Monetarios y Financieros (CEMFI)
}

Diciembre de 2012

\begin{abstract}
Using data on Uruguayan adolescents, we estimate peer effects in risk attitudes. Relative risk aversion is elicited in an experimental setting. Identification is based on parents not being able to choose the class within the school of their choice. After controlling for school-grade fixed effect and addressing endogeneity due to simultaneity, we find a significant and quantitative large impact of peers on individuals risk aversion. An increase in one standard deviation of the group risk aversion produces an increase in $44-64 \%$ on an individual risk aversion. These findings enhance the importance of multiplicative effects related to risk behavior.
\end{abstract}

JEL classification: I12; D1.

Keywords: risk aversion; peer effects; instrumental variables.

Documento de Investigación, Nro. 84, Diciembre de 2012. Universidad ORT Uruguay. Facultad de Administración y Ciencias Sociales. ISSN 1688-6275

Corresponding author: Néstor Gandelman

Address: Universidad ORT Uruguay, Bulevar España 2633, Montevideo 11.300, Uruguay

Phone: 59827071806

Email: gandelman@ort.edu.uy 


\section{Introduction}

The "Not Me, Not Now" website is part of a social marketing campaign to prevent teen pregnancy. "Just Say No" was a similarly spirited advertising campaign to discourage children from engaging in illegal drug use. These are examples of social programs aiming at reducing the negative impact of peers in adolescents. These programs and others implicitly assume that adolescents engage in risky behavior as a result of social pressure. The assumption is that adolescents mimic others' risky behavior or they follow what is the "expected" or "desired" behavior by the group. In this paper we provide evidence of the existence of a different channel. We study the impact of peers in the coefficient of risk aversion. By focusing on economic fundamentals rather than behavioral outcomes, we provide a possible alternative explanation for a wide range of peer effects reported in the literature.

In the early psychology literature, risk taking was considered a personal attribute (see Bromiley and Curley (1992) for a literature review). More recently, it has been regarded as a multi-dimensional construct including elements of learning and experience. Zaleskiewicz, (2001) distinguishes two types of risk taking: instrumental and stimulating. Risk taking is instrumental when risk is a "bad" necessary to achieve a certain goal (e.g. investing in a certain financial project), and stimulating risk taking is related to a need of more immediate sensations and excitement (e.g. gambling). Loewenstein et al. (2001) propose that while people evaluate risks cognitively, they react to them emotionally.

Dohmen et al. (2010) present evidence that children's risk preferences are similar to their parents'. A partial explanation can be found in Cesarini et al. (2010) who find, based on a twin study, that approximately $25 \%$ of individual variation in portfolio risk can be attributed to genetic characteristics. Dohmen et al. (2010) show, on the other hand, that the similarity between parents and children is stronger for first-born children compared to younger siblings. Also, Booth and Nolen (2012) showed, in a controlled experiment with school students, that girls' risk preferences are affected by the gender composition of the group. Thus, there must be a channel of learning and or mimicking besides genetics. Moreover, Cesarini et al. (2010) acknowledge that although their results suggest there is a genetic variation in willingness to take financial risk, the mechanisms are not clear: genes could have a direct impact in financial decisions or the genotypes could select people into different environments that lead them to invest differentially. In the latter case, the genetic variation associated with investment variation is mediated by the environment. 
Documento de Investigación - ISSN 1688-6275 - No. 84 - 2012 - Balsa, A., Gandelman, N., González, N.

In sum, the literature suggests that risk attitudes are determined by many channels including inherent cognitive abilities, emotions and mimicking of relevant individuals (like parents). Peer effects in risk aversion are most likely to be the result of mimicking and habit formation processes.

In this paper we empirically assess the evidence on peer effects in risk attitudes by using a sample of secondary school adolescents. The economic literature has reported peer effects in a variety of settings including consumption of substances (Gavira and Raphael, (2001); Powell et al., (2005); Lundborg, (2006); Clark and Lohéac, (2007); Trogdon et al., (2008); Fletcher, (2012)), stock market participation (Hong et al., (2004)), trading decisions ( $\mathrm{Ng}$ and $\mathrm{Wu},(2010)$ ), and criminal recidivism (Bayer et al., (2009)), among others. In all of these cases individuals have to make decisions under uncertain conditions. One popular explanation for the existence of peer effects is that social pressure induces people to behave similarly to others. This explanation either implies that individuals make suboptimal decisions or that there are costs associated with departing from peers' standards of behavior (one such model is proposed by Daido (2004)). Alternatively, we could think that some parameters of the decision making process are affected by peers. If the basic risk aversion attitude is affected by peers through social learning (Bandura, (1973)), we would also find peer effects in decisions involving uncertainty and risk as those previously summarized.

One problem with the measurement of peer effects is that it is hard to disentangle peer influence from self-selection into groups of similar people. Peer correlations in economic attitudes and behaviors can be explained by selective group formation -- that is, the tendency for those with similar preferences, information and behavior patterns to get together. For example, parents are likely to choose their children's school according to their preferences. Due to this sorting, it is natural to find that students share more characteristics (e.g. religion) within schools than between schools. In this paper, we try to distinguish selective associations from influence by focusing on variations in attitudes within the same school. We use a database of 660 adolescents from 8 private schools in Uruguay. Our identification strategy is based on parents not being able to choose the class in which their children will be placed within their age cohort, a decision usually made in Uruguay by school authorities with the purpose of balancing behavior and performance across groups.

Our measure of individual risk aversion is similar to that proposed by Holt and Laury (2002). Students choose between a series of simple lotteries that, under certain 
assumptions, allow the computation of measures of relative risk aversion. This is a concept that adolescents are not familiar with and there is not a "socially expected" answer. Using a similar approach, Barksy et al. (1997) found that this measure of risk tolerance is correlated with risky behaviors like smoking, drinking, failing to insure, and holding stocks rather than Treasury bills.

Our paper is close in some aspects to Ahern et al. (2012) who use a random assignment of MBA students to test peer effects in risk aversion, honesty, altruism and trust. One important difference between their study and ours' is that we use a "more general" population: we study $9^{\text {th }}$ and $10^{\text {th }}$ grade adolescents while they focus on MBA students, who are clearly more business-oriented than the rest of the population. Adolescents, on the other hand, have much less experience regarding financial risk. Another distinction is that Ahern et al. (2012) use Holt and Laury's (2002) price list design to elicit risk aversion. This methodology demands some nontrivial computations on the part of the respondents (which may not be a problem for MBA students but would be for adolescents). In order to eliminate unnecessary difficulties for the students we use a simplified version of Holt and Laury's (2002) procedure. Ahern et al. (2012) uses an ordinal indicator of risk-aversion while we use a cardinal indicator of risk aversion whose main advantage is that it allows for an assessment of the magnitudes of the peer effects. As a robustness check, we use the ordinal indicator.

Our results suggest that an increase in one standard deviation in the peers' average risk aversion increases an individual's risk aversion between $44 \%$ and $64 \%$. Our results for males are robust to several alternative specifications, while the results for females are weaker.

The paper proceeds as follow. Section 2 introduces the methodology used to measure risk aversion and estimate peer effects. In Section 3 we describe the data. Section 4 presents the results and we conclude in Section 5.

\section{Methodology}

\section{a. Measuring risk aversion}

To obtain measures of risk aversion we follow a variation of the multiple price list design proposed by Holt and Laury (2002). Students were asked 10 times to choose between a secure payment (option A) and a lottery (option B). The lottery had one high (\$45) and one low (\$5) payment each with a $50 \%$ chance. The secure payment started at $\$ 35$ and 
was reduced in each subsequent question until it reached $\$ 10$ in the tenth question. An extremely risk averse individual will prefer always option A over B, while an extremely risk lover individual will always prefer option B over $A$. The question on which a student moves from option A to option B gives a range estimate of risk aversion.

Our procedure simplifies Holt and Laury's (2002) price list design in the following way: i) rather than comparing two lotteries, each question compares a single lottery against a secure payment, ii) the lottery is always the same in the 10 questions, the only thing that changes is the secure payment, iii) the probability of each payment is $50 \%$ and can be understood as a flip of a coin. In Table 1 we present both our procedure and Holt and Laury's. While our original paired choices were expressed in local currency, we present them in US dollars for ease of exposition.

\section{<TABLE 1 ABOUT HERE>}

A risk neutral person would choose option A four times before switching to B. Assuming a constant relative risk aversion function, it is possible to calculate, as in Holt and Laury (2002), an interval estimate of the coefficient of relative risk aversion $\rho$.

$u(y)=\left\{\begin{array}{lll}\frac{y^{1-\rho}}{1-\rho} & \text { if } & \rho \neq 1 \\ \log (\mathrm{y}) & \text { if } & \rho=1\end{array}\right.$

The coefficient of relative risk aversion of an individual that chooses four times A before switching to B must satisfy:

$$
\begin{aligned}
& u(26.2) \geq 0.5 u(45)+0.5 u(5) \\
& u(23.7) \leq 0.5 u(45)+0.5 u(5)
\end{aligned}
$$

Plugging (1) into (2) we get that this individual must have a coefficient of relative risk aversion between -0.135 and 0.137 , the midpoint being risk neutrality. The values of the secure payments were chosen so that the ranges are the same as in Holt and Laury (2002). Table 2 presents the ranges for all possible answers. In our estimations, we use the midpoint of each interval as the measure of individual risk aversion. We discarded those individuals that switch back and forth between A and B (who probably did not understand the question) and those individuals with extreme answers, who always preferred $\mathrm{A}$ to $\mathrm{B}$ or B to $\mathrm{A}$.

$<$ TABLE 2 ABOUT HERE $>$ 
Figure 1 plots the empirical distribution of the risk aversion coefficient. We observe a large density mass around 0.5 .

\section{b. Estimating peer effects}

The estimation of peer effects is challenged by at least three problems: i) the definition of the relevant reference group, ii) self-selection of individuals into groups of people with similar characteristics, and iii) the bi-directionality of influences between the individual and his/her peers (Mansky's (1993) reflection problem).

Parents select schools for their children based on their preferences for location, quality, costs, and other school features. As a result of this self-selection, students get sorted across schools. While parents can select schools, they are less likely to be able to select the particular class within a school cohort where his/her child will be placed. The assignment of students across classes in Uruguay is majorly a decision of the school authorities, who seek to balance student characteristics across the different groups. ${ }^{1}$ This decision relies on the advice of professionals at each educational center and discourages parental intervention. Groups are reorganized every year or every couple of years, depending on the school. While the assignment process is not random, it relies on avoiding sorting of equals within classes and none of the schools have tracking rules in the assignment of students. Moreover, in all schools the same professors teach all the classes within a grade (except in rare cases). Our identification strategy relies on comparing groups of children that have been assigned to different classes within their school cohort. The strategy is similar to that in Lundborg (2006) who studies peer effects in substance use among adolescents or Ammermueler and Pischke (2009) who test for peer effects in reading scores. Because of the balancing nature of class assignment, we are confident that any remaining selection in the process would work against our effect of interest. In other words, we are unlikely to confound peer influence with selection into groups of equals because the class assignment process is aimed at attaining balance between classes. As in Ammermueler and Pischke (2009), the variation in our peer variable most likely reflects the small differences in composition when multiple groups are formed out of a small population (the absence of the law of large numbers). Finally, by controlling for schoolgrade fixed effects, we are able to get rid of unobserved heterogeneity at the school level that could be correlated with an adolescent's behavioral choices.

We choose to work with one of the reference groups most likely to have an influence on the adolescent: his/her classmates. Whether this group of influence includes males and females or only same gender individuals is an empirical matter. Our analysis

${ }^{1}$ We interviewed principals at each school to understand the nature of students' assignment to classes. 
considers both possibilities: the relevant peer group is defined first as the full class to which the student has been assigned, and then as the same sex individuals within the class.

For each individual i, we define his/her peer group's average attitude towards risk as:

$$
P_{i g g e}=\frac{\left(\Sigma_{i j} y_{j g c}\right)-y_{i g g c}}{N_{s g c}-1}
$$

where $y_{j s g c}$ is the measure of risk aversion of student $j$ in school $s$, grade $g$, and class $c$, and $N_{s g c}$ the number of students in school $s$, grade $g$, and class $c$.

Our econometric model is given by the following parameterization,

$$
y_{i g g z}=\alpha_{0}+\alpha_{1} P_{i g g e}+\alpha_{2} X_{i g g e}+\alpha_{3} X_{\text {sge }}+\gamma_{s g}+\varepsilon_{\text {sge }}+u_{i g g e}
$$

where $X_{i s g c}$ is a vector of individual and family characteristics of the $i$ th student and $X_{s g c i s}$ a vector with the average demographic characteristics of students in school $s$, grade $g$, and class $c$ (both vectors will be described thoroughly in the next section). $\gamma_{s g}$ is a vector of school and grade dummies. The error term includes an idiosyncratic individual-specific error term, $u_{i s g c a n d}$ an error term at the reference group level, $\varepsilon_{s g c}$.

As mentioned above, the problem of selection is addressed by adjusting for the vector of school and grade dummies, $\gamma_{s g}$. By controlling for these fixed effects, we compare students of similar characteristics (students that belong to the same school and age cohort) that have been exogenously assigned into classrooms. This dismisses the concern that common unobserved heterogeneity drives any association between the individual's attitude towards risk and those of his/her peers.

The estimation of (4) with ordinary least squares has the additional problem of bidirectionality, or Manski's reflection problem. The issue stems from the simultaneity of influences between an individual and his peers; i.e. does the group affect the individual or does the individual affect the group? We address this endogeneity by using instrumental variables. The idea is to find an instrument correlated with peers' attitudes towards risk but uncorrelated to the individual's risk attitude. As in prior literature (Gaviria and Raphael (2001); Powell et al. (2005); Lundborg (2006); Clark and Lohéac (2007); Trogdon et al., (2008); Fletcher, (2012)), we use peers' family background characteristics as instruments because they have been associated with children's risk attitudes and behaviors (Dohmen et al., (2010)). Furthermore, the peer group's family background is unlikely to be affected by an individual's contemporaneous attitudes or behavior. 
Finally, we address the potential correlation of errors within reference groups by clustering standard errors at the school-grade-class level. ${ }^{2}$

\section{Data}

This paper uses a database of 1047 adolescents attending third and fourth year of secondary school in 10 private schools in Montevideo, Uruguay (see Balsa et al. (2010) for further details). The majority of these students were between 14 and 16 years old in 2009. Each student was asked to complete a detailed survey, originally aimed at evaluating the effectiveness of a health promotion activity. A variety of information was collected on substance use, sexual activity, violence, leisure and socio-demographics. The surveys were self-administered by students at schools with the supervision and help of research staff and took about one hour to complete.

Because our identification strategy depends upon the use of school-grade fixed effects (and the comparison of classes within school-grade), we dropped from the original sample two schools that had a single class in each grade. We also excluded adolescents with extreme answers to the risk aversion questions (those choosing always option A or B, extremely risk averse or extremely risk lover, respectively) and those with illogical answers (switching back and forth between A and B). Finally, we excluded individuals with missing data in at least one of the relevant variables. The final sample includes 660 observations corresponding to 43 classes and 8 schools.

To test whether students' placement into classes proxies random assignment, we construct, for each relevant student characteristic, a Pearson chi square test of the difference in the variable mean across classes within grades. Under the assumption that schools are independent, we can sum up these chi square statistics across schools and construct a balancing test for each characteristic in the sample (see Ammermueler and Pischke (2009). Appendix Table A1 shows these statistics for age, gender, mother's education, single mother family, intact family, number of siblings, asset index, and father and mother's working status. For most variables, we find that assignment of students to classes does not depend on these characteristics. There is a statistically significant difference in the number of siblings for $4^{\text {th }}$ grade and a difference in the single-family category for $3^{\text {rd }}$ grade, but only at a significance level of $10 \%$.

\footnotetext{
2 Angrist and Pischke (2010) provide 42 as a rule of thumb for how many clusters are necessary for clustering to work. Our number of cluster depends on the specification, but is around this benchmark.
} 
Table 3 shows summary statistics of the risk aversion measures at the individual and group level for the full sample and by gender. The main outcome of interest is the risk aversion coefficient, defined as the midpoint of the bounds in Table 2. The average of this variable is 0.5 , with a standard deviation of 0.64 , a minimum value of -1.35 and a maximum of 1.53. These values are below empirical estimates of the coefficient of relative risk aversion for adults, but in line with evidence that adolescents are more inclined toward risky behavior and risky decision making than are adults (Gardner and Steinberg (2005); Steinberg, (2006)). The estimates also show that the average male has a lower risk aversion than the average female, a difference also pointed out in the literature (Croson and Gneezy (2009), Eckel and Grossman, (2008)) but not statistically significant in our analysis.

As a cruder measure of risk aversion, we also compute the question number in which the student switched from option A to option B, which unlike the coefficient, is just an ordinal indicator of risk attitudes. Both males and females switch, in average, in question number 7. For the latter quantification of the peer effects in the results section we include the average of the peer group measure which is equal to the average of risk aversion at the individual level. The median of the reference group is quite similar to the average.

\section{<TABLE 3 ABOUT HERE>}

Table 4 shows socio-demographic characteristics of the selected sample, as well as some class features and markers of risky behavior. Students are in average 15 years old; $54 \%$ are in $4^{\text {th }}$ grade of secondary school and $46 \%$ are in $3^{\text {rd }}$ grade. Compared to the average teenager, students who attend private secondary schools in Uruguay have higher socio-economic status than students attending public schools. In average, the mothers of the students under study have 14 years of education (i.e. are high school graduates with some college). Nearly $70 \%$ of students have intact family structures and the average number of siblings is 1.2 . The employment rate is $85 \%$ for mothers and $94 \%$ for fathers, and $76 \%$ of working fathers are white collar. The average class size is 24 .

\section{$<$ TABLE 4 ABOUT HERE>}

Other variables we consider are: the frequency of alcohol consumption in the last 30 days, which takes five values $(0,2,6,16$ and 26 days); frequency of cigarette consumption in the last 30 days, taking the values $0,2,6,14,24$ and 30; and frequency of marihuana consumption in the last 3 months, which takes the values $0,3,12,18,42$ and 78 days. In average, the frequency of alcohol consumption and of smoking is around two 
days per month and the average frequency of marihuana consumption is 1.2 days in the past 3 months. Girls are more likely to smoke cigarettes, but boys are more likely to consume marihuana compared to girls. No differences are observed in alcohol consumption across genders.

In Appendix Table A.2 we compare the characteristics of the working sample against those observations excluded from the analysis. Most background variables are not statistically different across both samples. There are some minor differences in the education of the mother (those excluded are slightly less educated) and in the likelihood of having a white collar father (those excluded are less likely to have one). Concerning to some class features, the proportion of fourth grade students is greater in the analysis sample. The latter explains the differences in the average age between samples. In addition, there are some slight differences in both the average class size and the average number of female students in each class between samples. On the other hand, there are stronger differences in the likelihood of using substances: those excluded have a higher frequency of cigarette consumption (2.6 versus 2 days in the past month) and a higher frequency of marihuana use (1.7 days versus 1.2 days in the past 3 months). Nevertheless, those differences are not statistically significant.

\section{$<$ TABLE A1 ABOUT HERE>}

\section{Results}

Table 5 shows instrumental variables estimates of social-multiplier effects in risk aversion. The first column shows results for the full sample when the reference group is defined as both boys and girls in the class; the second column depicts estimates for the full sample but only with classmates of the same sex as the reference group; the third and fourth column share the specification in column 2, but restricting the sample to males and females respectively. ${ }^{3}$ All estimations control for school-grade fixed effects, and standard errors are clustered at the class level. The set of instruments used to predict peer groups' risk attitudes are mother's education, mother's education squared, intact family structure and single mother household.

The first stage of the 2SLS estimates (depicted in Table A3) shows that the instruments are relevant at explaining the peer group's measure of risk aversion for males but not for females. Average risk aversion for males decreases with mother's education, and with intact or single-mother family structure (relative to alternative family

${ }^{3}$ When we focus on classmates of their own sex, two classes are missed because of the lack of at least two observations to construct the peer group variable. 
Documento de Investigación - ISSN 1688-6275 - No. 84 - 2012 - Balsa, A., Gandelman, N., González, N.

structures). The test of weak identification of Kleibergen- Paap ( $r k$ test) ${ }^{4}$ - displayed at the bottom of Table 5-satisfies Staiger and Stock's (1997) rule of thumb of 10 only when analyzing the sample of male students (F-value of 12.5). It is quite irrelevant, though, in the case of females (F-value of 0.746 ), and relatively weak when analyzing the full sample (F-value of 5.8 when the peer group is defined as the full class, and F-value of 3.0 when the peer group includes only same-gender classmates). Hahn et al. (2004) provide evidence that the GMM continuously updated estimator (CUE) ${ }^{5}$ performs better than the 2SLS and GMM estimators under the weak instrument problem. And unlike the limited-information maximum likelihood (LIML) estimator -suggested also as an alternative in the context of weak instruments-, the CUE approach does not require the assumption of i.i.d. errors. We thus use the GMM CUE technique to estimate peer effects in risk aversion. Because standard statistical inference is not robust to the weak identification problem, we use the Anderson and Rubin's (1949) test for inference. This test is robust to weak instruments even under the assumption of non i.i.d errors.

Table 5 reports CUE coefficients, standard errors (in parentheses) and p-values for the AR chi-squared test (in brackets). ${ }^{6}$ The estimates suggest economically strong and statistically significant effects of the peer group's risk attitude both when the full sample is analyzed and when the analysis is conducted on male students. For males, a one point increase in his same-sex classmate's average coefficient of risk aversion translates into a 1.2 increase in individual risk aversion. Despite being statistically insignificant, the coefficient on peer group risk aversion for females is on the same order. The effects are also similar in magnitude and statistically significant for the full sample, regardless of whether the reference group is the full class or only the same-gender classmates.

\section{$<$ TABLE 5 ABOUT HERE>}

The standard deviation of the peer group's risk aversion is 0.176 (see first column in Table 3) when the reference group is defined as all boys and girls in the class. Translating the results in column 1 of Table 5 to standard deviations, a one standard deviation increase in the peer group risk aversion shifts upwards a student's risk aversion coefficient by 0.224 , a $44 \%$ increase relative to the average risk aversion coefficient of 0.511 . When the peer group is defined as all same-sex classmates the estimated coefficient

${ }^{4}$ The rk test is a Wald F statistic similar to Cragg and Donald's (1993), but constructed assuming a robust covariance matrix rather than i.i.d. errors.

${ }^{5}$ Developed by Hansen et al. (1996).

${ }^{6}$ The AR test has the chi-square and the F-statistic version. Both of them are a Wald test (with the correspondingly robust covariance matrix in the absence of the i.i.d assumption) with the null hypothesis that the coefficient of the peer group variable (the endogenous variable that we want to identify) in the structural form are jointly equal to zero. Since we have not found evidence of superiority of one version over the other we present both. 
is 1.236 (column 2 of Table 5) and the standard deviation for this group is 0.262 (column 1 of Table 3). Therefore, in this case one standard deviation of the peer group's risk aversion produces a grater increase in individual risk aversion (63\%). Doing the same exercise, columns 3 and 4 suggest that for both boys and girls an increase in one standard deviation produces an increase in individuals risk aversion of $61 \%$ and $64 \%$, respectively.

Table 6 reports various robustness checks. First, we consider an alternative risk aversion measure defined as the question number in which the student switched from answer A to B (an ordinal indicator of risk aversion as in Ahern et al. (2012)). This variable takes 9 discrete values, with higher values indicating higher levels of risk aversion. Results are in line with the previous findings: we identify peer effects in risk aversion for the full sample (both when the reference group is the full class or the same-sex classmates) and for the sample of males. Effects are smaller and non-significant in the case of females.

Second, we use the median of the coefficient of risk aversion of the reference group as the relevant peer group measure. The advantage of the median is that it is more robust to outliers. Again, we observe statistically significant effects for the full sample and in the case of males.

Third, we re-estimate the model including observations that had been a priori excluded from the sample due to extreme values in the risk aversion coefficient (i.e. cases in which the student chose always option A or always option B). For these extreme cases, we imputed values that were one time and a half below (above) the lowest (upper) risk aversion thresholds identified in Table 2 (1.5 times -1.749 and 1.5 times 1.742 in the lower and upper extremes respectively). We also experimented imputing other values, such as twice the midpoint of the lowest or highest interval. Results keep being robust for males, but are now non-significant for the full sample.

\section{<TABLE 6 ABOUT HERE>}

An alternative explanation for the pattern of correlated risk preferences would be the presence of class-level common shocks to the measurement of preferences or to preferences per se. We believe the former explanation is quite unfeasible given the process of data collection. Surveys were self-administered during class-time; students were closely supervised by research staff and unable to talk to each other. The research staff was trained to respond to students' questions without interference. Regarding the possibility of common shocks to preferences, we believe we are dismissing an important 
set of common shocks by controlling for school fixed effects. At the class-level, we are not worried about common shocks coming from teachers, because the same teachers teach both classes (saving exceptional cases) in all schools. We cannot completely dismiss other common shocks to preferences stemming from unobserved events (a particular influential lecture, differential treatment by the principal, and so forth).

\section{Conclusions}

Many studies in economics and other social sciences have focused on the identification of peer effects in the use of substances and other risky behaviors. The mechanisms behind these effects are still unclear, though. While peer effects in behavioral outcomes have been partly attributed to social pressure, they could also stem from the mimicking of economic attitudes or preference fundamentals, such as risk aversion, across peers ${ }^{7}$.

This paper provides evidence for the latter mechanism. Using a database of adolescents, we assess whether student's attitudes towards risk are affected by the attitudes of their peers. We find strong evidence of peer effects in risk aversion for male adolescents: a one standard deviation increase in the average coefficient of risk aversion of male classmates increases a student's risk aversion by $44 \%$. The evidence is weaker for females, probably due to our failure to find relevant instruments for the GMM estimation. As in Booth and Nolen (2012), our results suggest that the observed gender differences in behavior under uncertainty found in previous studies might be the result of social learning.

Our paper has several methodological strengths. First, our rich database enables us to control for selection of individuals into groups of similar peers and to address the problem of simultaneity of influences between an individual and his/her group of influence. Specifically, we use school-grade fixed effects to address selection and compare the influence of peers across different classes in the same school. We tackle the simultaneity problem by using instrumental variables that project the group's risk attitudes on the group's family background characteristics. Second, unlike prior research, we employ a cardinal measure of risk attitudes, which allows us to assess the magnitude of multiplicative social effects.

There are also some limitations to our analysis. Students face no financial stakes associated to their choice of options in the price list used to assess risk attitude. This may limit the accuracy of the risk aversion measures. An additional problem is that some selection may persist if parents are able to manipulate in some way the class assignment

${ }^{7}$ Individuals with higher risk aversion are less likely to use drugs, drive under the influence, or have risky sex. 
of their children. While class assignment is usually within the school administrator's scope in Uruguay, we cannot totally dismiss this possibility. Finally, our small sample size restricts us from finding relevant instruments for females and is ultimately responsible for the lack of precision in the female estimates.

Overall, we believe our findings shed light on the importance of social multiplier effects in attitudes towards risk. By focusing on economic fundamentals, rather than on concrete behavioral outcomes, our analysis provides insight into a particular mechanism that may shape decision-making under uncertainty and drive risky behavior. The policy implications of a channel based upon the contagion of preference parameters is quite different to that stemming from social pressure. Policies promoting individual reaction to social pressure such as "Say No to Drugs" may be quite ineffective if peer influence in risky behaviors works mostly through the mimicking of risk attitudes. 
Documento de Investigación - ISSN 1688-6275 - No. 84 - 2012 - Balsa, A., Gandelman, N., González, N.

\section{References}

Ahern, K., R. Duchinand and T. Shumway (2012). "Peer effects in economic attitudes". Social Science Research Network, Working Paper Series.

Anderson, T. W. and H. Rubin (1949). "Estimation of the parameters of a single equation in a complete system of stochastic equations". Annals of Mathematical Statistics, vol. 20(1), pp. 46-63.

Balsa, A., N. Gandelman and R. Porzecanski (2010). "The impact of ICT on adolescents' perceptions and consumption of substances". Inter American Development Bank Working Paper Series № 219.

Barsky, R. B., F. T. Juster, M. S. Kimball and M. D. Shapiro (1997). “Preference parameters and behavioral heterogeneity: an experimental approach in the health and retirement study". Quarterly Journal of Economics, vol. 112(2), pp. 537-579.

Booth, A. L. and P. Nolen (2012). "Gender differences in risk behaviour: does nurture matter?". The Economic Journal, vol. 122(558), pp. F56-F78.

Bayer, P., R. Hjalmarsson and D. Pozen (2009). "Building criminal capital behind bars: peer effects in juvenile corrections”. Quarterly Journal of Economics, vol. 124, (1), pp. 105-47.

Bromiley, P. and S. Curley (1992). "Individual differences in risk taking". in Risk taking behaviour, edited by F. Yates, pp. 87-132. Wiley, Chichester.

Cesarini, D., M. Johannesson, P. Lichtenstein, O. Sandewall, and B. Wallace (2010). “Genetic variation in financial decision-making”. Journal of Finance, vol. 65(5), pp. 1725-1754.

Cragg, J. G. and S. G. Donald (1993). "Testing identifiability and specification in instrumental variables models". Econometric Theory, vol. 9(2), pp. 222-240.

Croson, R and U. Gneezy (2009). "Gender differences in preferences". Journal of Economic Literature, vol. 47(2), pp. 448-74.

Daido, K. (2004). "Risk averse agents with peer pressure”. Applied Economics Letters, vol. 11(6), pp. 383-386.

Clark, A., and Y. Lohéac (2007). "It wasn't me, it was them! Social influence in risky behavior by adolescents". Journal of Health Economics, vol. 26(4), pp. 763-784.

Dohmen, T., A. Falk, D. Huffman and U. Sunde (2010). "The intergenerational transmission of risk and trust attitudes". IZA Discussion Paper No 2380.

Eckel, C., and P.J. Grossman (2008). "Men, women and risk aversion: experimental evidence". Handbook of Experimental Economics Results, vol. 1, pp. 1061-1073.

Fletcher, J.M. (2012). "Peer influences on adolescent alcohol consumption: evidence using an instrumental variable/fixed effects approach". Journal of Population Economics, vol. 25(4), pp. 1265-1286.

Gardner, M. and L. Steinberg (2005). "Peer influence on risk taking, risk preference, and risky decision making in adolescence and adulthood: an experimental study". Developmental Psychology, vol. 41(4), pp. 625-635.

Gavira, A. and S. Raphael (2001). "School-based peer effects and juvenile behavior". Review of Economics and Statistics, vol. 83(2), pp. 257-268. 
Hahn, J., J. Hausman and G. Kuersteiner (2004). "Estimation with weak instruments: accuracy of higher-order bias and MSE approximations". Econometrics Journal, vol. 7(1), pp. 272-306.

Hansen, L., J. Heaton and A. Yaron (1996). "Finite sample properties of some alternative GMM estimators". Journal of Business and Economic Statistics, vol. 14(3), pp. 262-280.

Holt, C., and S. Laury (2002). "Risk aversion and incentive effects". American Economic Review, vol. 92(5), pp. 1644-1655.

Hong, H., J. Kubik and J. Stein (2004). "Social interaction and stock-market participation". Journal of Finance, vol. 59(1), pp. 137-163.

Kleibergen, F. and R. Paap (2006). "Generalized reduced rank tests using the singularvalue decomposition". Journal of Econometrics, vol. 133(1), pp. 97-126.

Mansky, C.F. (1993), "Identification of endogenous social effects: the reflection problem". Review of Economic Studies, vol. 60(3), pp. 531-542.

$\mathrm{Ng}$, L. and F. Wu (2010). "Peer effects in the trading decisions of individual investors". Financial Management, vol. 39(2), pp. 807-831.

Loewenstein, G. F., E. U. Weber, C. K. Hsee, and N. Welch (2001). "Risk as Feelings". Psychological Bulletin, vol. 127(2), pp. 267-286.

Lundborg, P. (2006). "Having the wrong friends? Peer effects in adolescent substance use". Journal of Health Economics, vol. 25(2), pp. 214-233.

Powell, L.M., J.A. Tauras and H. Ross (2005). "The importance of peer effects, cigarette prices and tobacco control policies for youth smoking behavior". Journal of Health Economics, vol. 24(5), pp.950-968.

Staiger, D. and J. H. Stock (1997). "Instrumental variables regression with weak instruments". Econometrica, vol. 65(3), pp. 557-586.

Steinberg, L. (2006). "Risk taking in adolescence: what changes and why?". Annals of the New York Academy of Sciences, vol. 1021(1), pp. 51-58.

Trogdon, J., J. Nonnemaker and J. Pais (2008). "Peer effects in adolescent overweight". Journal of Health Economics, vol. 27(5), pp. 1388-1399.

Zaleskiewicz, T. (2001). "Beyond risk seeking and risk aversion: personality and the dual nature of economic risk taking". European Journal of Personality, vol. 15(S1), pp. S105S122. 
Documento de Investigación - ISSN 1688-6275 - No. 84 - 2012 - Balsa, A., Gandelman, N., González, N.

\begin{tabular}{|c|c|c|}
\hline \multicolumn{3}{|c|}{ Holt \&Laury (2002) } \\
\hline & Option A & Option B \\
\hline 1 & $1 / 10$ of $\$ 2.00,9 / 10$ of $\$ 1.60$ & $1 / 10$ of $\$ 3.85,9 / 10$ of $\$ 0.10$ \\
\hline 2 & $2 / 10$ of $\$ 2.00,8 / 10$ of $\$ 1.60$ & $2 / 10$ of $\$ 3.85,8 / 10$ of $\$ 0.10$ \\
\hline 3 & $3 / 10$ of $\$ 2.00,7 / 10$ of $\$ 1.60$ & $3 / 10$ of $\$ 3.85,7 / 10$ of $\$ 0.10$ \\
\hline 4 & $4 / 10$ of $\$ 2.00,6 / 10$ of $\$ 1.60$ & $4 / 10$ of $\$ 3.85,6 / 10$ of $\$ 0.10$ \\
\hline 5 & $5 / 10$ of $\$ 2.00,5 / 10$ of $\$ 1.60$ & $5 / 10$ of $\$ 3.85,5 / 10$ of $\$ 0.10$ \\
\hline 6 & $6 / 10$ of $\$ 2.00,4 / 10$ of $\$ 1.60$ & $6 / 10$ of $\$ 3.85,4 / 10$ of $\$ 0.10$ \\
\hline 7 & $7 / 10$ of $\$ 2.00,3 / 10$ of $\$ 1.60$ & $7 / 10$ of $\$ 3.85,3 / 10$ of $\$ 0.10$ \\
\hline 8 & $8 / 10$ of $\$ 2.00,2 / 10$ of $\$ 1.60$ & $8 / 10$ of $\$ 3.85,2 / 10$ of $\$ 0.10$ \\
\hline 9 & $9 / 10$ of $\$ 2.00,1 / 10$ of $\$ 1.60$ & $9 / 10$ of $\$ 3.85,1 / 10$ of $\$ 0.10$ \\
\hline 10 & $10 / 10$ of $\$ 2.00,0 / 10$ of $\$ 1.60$ & $10 / 10$ of $\$ 3.85,0 / 10$ of $\$ 0.10$ \\
\hline \multicolumn{3}{|c|}{ Our paired choices\# } \\
\hline & Option A (sure bet) & Option B (lottery) \\
\hline 1 & $\$ 35.00$ & $50 \%$ of $\$ 45,50 \%$ of $\$ 5$ \\
\hline 2 & $\$ 31.75$ & $50 \%$ of $\$ 45,50 \%$ of $\$ 5$ \\
\hline 3 & $\$ 29.00$ & $50 \%$ of $\$ 45,50 \%$ of $\$ 5$ \\
\hline 4 & $\$ 26.20$ & $50 \%$ of $\$ 45,50 \%$ of $\$ 5$ \\
\hline 5 & $\$ 23.70$ & $50 \%$ of $\$ 45,50 \%$ of $\$ 5$ \\
\hline 6 & $\$ 20.90$ & $50 \%$ of $\$ 45,50 \%$ of $\$ 5$ \\
\hline 7 & $\$ 19.10$ & $50 \%$ of $\$ 45,50 \%$ of $\$ 5$ \\
\hline 8 & $\$ 15.25$ & $50 \%$ of $\$ 45,50 \%$ of $\$ 5$ \\
\hline 9 & $\$ 12.50$ & $50 \%$ of $\$ 45,50 \%$ of $\$ 5$ \\
\hline 10 & $\$ 10.00$ & $50 \%$ of $\$ 45,50 \%$ of $\$ 5$ \\
\hline
\end{tabular}

\# The choices were presented to students in Uruguayan currency. For ease of exposition, we converted all amounts to US currency using the average 2009 exchange rate. 


\begin{tabular}{lccl}
\hline \multicolumn{4}{c}{ Table 2. Implied risk aversion ranges assuming a CRRA utility function } \\
\hline Lottery preferences & Range estimate & Characterization \\
Always B & Below & -1.749 & Extremely risk loving \\
Option A up to 1 and switch to B at 2 & -1.749 & -0.948 & \\
Option A up to 2 and switch to B at 3 & -0.948 & -0.494 & \\
Option A up to 3 and switch to B at 4 & -0.494 & -0.135 & Moderately risk loving \\
Option A up to 4 and switch to B at 5 & -0.135 & 0.137 & Risk Neutral \\
Option A up to 5 and switch to B at 6 & 0.137 & 0.414 & Moderately risk averse \\
Option A up to 6 and switch to B at 7 & 0.414 & 0.586 & \\
Option A up to 7 and switch to B at 8 & 0.586 & 1.000 & \\
Option A up to 8 and switch to B at 9 & 1.000 & 1.308 & \\
Option A up to 9 and switch to B at 10 & 1.308 & 1.742 & \\
Always A & Above & 1.742 & Extremely risk averse \\
\hline
\end{tabular}

Table 3. Summary statistics of risk aversion and peer measures.

\begin{tabular}{|c|c|c|c|c|}
\hline & $\begin{array}{c}\text { Full } \\
\text { sample } \\
(1)\end{array}$ & $\begin{array}{c}\text { Male } \\
(2)\end{array}$ & $\begin{array}{c}\text { Female } \\
(3)\end{array}$ & $\begin{array}{l}\text { Difference } \\
(2)-(3)\end{array}$ \\
\hline \multicolumn{5}{|l|}{ Outcome variables } \\
\hline Risk aversion coefficient & $\begin{array}{c}0.511 \\
(0.643)\end{array}$ & $\begin{array}{c}0.486 \\
(0.644)\end{array}$ & $\begin{array}{c}0.536 \\
(0.642)\end{array}$ & -0.050 \\
\hline Switching indicator & $\begin{array}{l}6.905 \\
(2.056)\end{array}$ & $\begin{array}{l}6.815 \\
(2.066)\end{array}$ & $\begin{array}{c}6.994 \\
(2.045)\end{array}$ & -0.179 \\
\hline \multicolumn{5}{|c|}{$\begin{array}{l}\text { Peer group measure of risk aversion } \\
\text { Reference group: all students in class }\end{array}$} \\
\hline Average of the peer group & $\begin{array}{c}0.511 \\
(0.176)\end{array}$ & $\begin{array}{c}0.512 \\
(0.192)\end{array}$ & $\begin{array}{c}0.507 \\
(0.159)\end{array}$ & 0.005 \\
\hline Median of the peer group & $\begin{array}{c}0.533 \\
(0.195)\end{array}$ & $\begin{array}{c}0.535 \\
(0.207)\end{array}$ & $\begin{array}{c}0.530 \\
(0.184)\end{array}$ & 0.005 \\
\hline \multicolumn{5}{|c|}{$\begin{array}{l}\text { Peer group measure of risk aversion } \\
\text { Reference group: same sex students in class }\end{array}$} \\
\hline Average of the peer group & $\begin{array}{c}0.511 \\
(0.262)\end{array}$ & $\begin{array}{c}0.484 \\
(0.264)\end{array}$ & $\begin{array}{c}0.535 \\
(0.259)\end{array}$ & $-0.052^{* * *}$ \\
\hline Median of the peer group & $\begin{array}{c}0.543 \\
(0.310)\end{array}$ & $\begin{array}{c}0.487 \\
(0.288)\end{array}$ & $\begin{array}{c}0.600 \\
(0.321)\end{array}$ & $-0.113^{* * *}$ \\
\hline Observations & 660 & 330 & 330 & \\
\hline
\end{tabular}

Note: Standard deviation in parenthesis

${ }^{*}$ Significant at $10 \%$ level; ${ }^{* *}$ Significant at $5 \%$ level; ${ }^{* * *}$ Significant at $1 \%$ level. 
Documento de Investigación - ISSN 1688-6275 - No. 84 - 2012 - Balsa, A., Gandelman, N., González, N.

Table 4. Summary statistics of characteristics.

\begin{tabular}{|c|c|c|c|c|}
\hline Variables & $\begin{array}{l}\text { Full sample } \\
\text { (1) }\end{array}$ & $\begin{array}{l}\text { Male } \\
(2)\end{array}$ & $\begin{array}{c}\text { Female } \\
\text { (3) }\end{array}$ & $\begin{array}{c}\text { Difference } \\
\text { (2) - (3) }\end{array}$ \\
\hline Age & $\begin{array}{l}15.343 \\
(0.603)\end{array}$ & $\begin{array}{l}15.390 \\
(0.592)\end{array}$ & $\begin{array}{l}15.295 \\
(0.611)\end{array}$ & $0.095^{* *}$ \\
\hline Mother's education & $\begin{array}{l}14.920 \\
(2855)\end{array}$ & $\begin{array}{l}14.859 \\
(2.904)\end{array}$ & $\begin{array}{l}14.981 \\
(2.808)\end{array}$ & -0.122 \\
\hline 4 th grade & $\begin{array}{c}0.536 \\
(0.499)\end{array}$ & $\begin{array}{c}0.579 \\
(0.495)\end{array}$ & $\begin{array}{c}0.494 \\
(0.501)\end{array}$ & $0.085^{* *}$ \\
\hline Single mother family & $\begin{array}{c}0.209 \\
(0.407)\end{array}$ & $\begin{array}{c}0.203 \\
(0.403)\end{array}$ & $\begin{array}{c}0.215 \\
(0.412)\end{array}$ & -0.012 \\
\hline Complete family structure & $\begin{array}{c}0.697 \\
(0.460)\end{array}$ & $\begin{array}{c}0.709 \\
(0.455)\end{array}$ & $\begin{array}{c}0.685 \\
(0.465)\end{array}$ & 0.024 \\
\hline Number of siblings & $\begin{array}{c}1.150 \\
(0.832)\end{array}$ & $\begin{array}{c}1.170 \\
(0.851)\end{array}$ & $\begin{array}{c}1.130 \\
(0.813)\end{array}$ & 0.040 \\
\hline Average age in class & $\begin{array}{l}15.368 \\
(0.477)\end{array}$ & $\begin{array}{l}15.414 \\
(0.468)\end{array}$ & $\begin{array}{l}15.322 \\
(0.483)\end{array}$ & $0.092^{* *}$ \\
\hline Average class size & $\begin{array}{l}23.536 \\
(4.951)\end{array}$ & $\begin{array}{l}23.430 \\
(4.966)\end{array}$ & $\begin{array}{l}23.642 \\
(4.940)\end{array}$ & -0.212 \\
\hline Mother works & $\begin{array}{c}0.845 \\
(0.362)\end{array}$ & $\begin{array}{c}0.852 \\
(0.356)\end{array}$ & $\begin{array}{c}0.839 \\
(0.368)\end{array}$ & 0.013 \\
\hline Father works & $\begin{array}{c}0.939 \\
(0.239)\end{array}$ & $\begin{array}{c}0.952 \\
(0.215)\end{array}$ & $\begin{array}{c}0.927 \\
(0.260)\end{array}$ & $0.025^{*}$ \\
\hline Father white collar & $\begin{array}{c}0.755 \\
(0.431)\end{array}$ & $\begin{array}{c}0.773 \\
(0.420)\end{array}$ & $\begin{array}{c}0.736 \\
(0.441)\end{array}$ & 0.037 \\
\hline $\begin{array}{c}\text { Frequency of alcohol consumption last } 30 \\
\text { days }\end{array}$ & $\begin{array}{l}1.924 \\
(2.549)\end{array}$ & $\begin{array}{c}2.067 \\
(2.738)\end{array}$ & $\begin{array}{c}1.782 \\
(2.339)\end{array}$ & $0.285^{*}$ \\
\hline $\begin{array}{l}\text { Frequency of cigarettes consumption last } \\
\qquad 30 \text { day }\end{array}$ & $\begin{array}{c}2.045 \\
(6.351)\end{array}$ & $\begin{array}{c}1.582 \\
(5.608)\end{array}$ & $\begin{array}{c}2.509 \\
(6.993)\end{array}$ & $-0.927^{* *}$ \\
\hline $\begin{array}{c}\text { Frequency of marihuana consumption } \\
\text { last } 3 \text { months }\end{array}$ & $\begin{array}{c}1.182 \\
(6.725)\end{array}$ & $\begin{array}{c}1.691 \\
(8.884)\end{array}$ & $\begin{array}{c}0.673 \\
(3.338)\end{array}$ & $1.018^{* *}$ \\
\hline Observations & 660 & 330 & 330 & \\
\hline
\end{tabular}

Note 1: Standard deviation in parenthesis

Note 2: Excluded observation are those students who: 1) belong to the two school that have only one class in each grade; 2) choose always option A or B (extreme values); 3 ) switch back and forth between A and B (illogic answers); and 4) do not answer one of the relevant questions for the analysis.

${ }^{*}$ Significant at $10 \%$ level; ${ }^{* *}$ Significant at $5 \%$ level; ${ }^{* * *}$ Significant at $1 \%$ level. 
Table 5. Peer effects in risk aversion. GMM Continuously updated estimator (CUE) estimates.

\begin{tabular}{|c|c|c|c|c|}
\hline \multirow[t]{2}{*}{$\begin{array}{c}\text { Dependent variable: Risk aversion } \\
\text { coefficient }\end{array}$} & \multirow{2}{*}{$\begin{array}{l}\text { Peer group: } \\
\text { full class } \\
\text { Full sample } \\
\text { (1) }\end{array}$} & \multicolumn{3}{|c|}{ Peer group: same sex students in class } \\
\hline & & $\begin{array}{l}\text { Full sample } \\
\quad(2)\end{array}$ & $\begin{array}{c}\text { Males } \\
(3)\end{array}$ & $\begin{array}{c}\text { Females } \\
\quad(4)\end{array}$ \\
\hline \multicolumn{5}{|l|}{ Main variable of interest } \\
\hline \multirow[t]{2}{*}{ Peer group average risk aversion } & $1.275^{* * *}$ & $1.236^{* * *}$ & $1.173^{* * *}$ & 1.271 \\
\hline & $(0.150)$ & $(0.177)$ & $(0.223)$ & $(0.272)$ \\
\hline Anderson-Rubin $F$ test ( $p$-value) & 0.000 & 0.030 & 0.000 & 0.479 \\
\hline Anderson-Rubin Chi sq test (p-value) & 0.000 & 0.017 & 0.000 & 0.406 \\
\hline \multicolumn{5}{|l|}{ Controls } \\
\hline \multirow[t]{2}{*}{ Age } & 0.015 & -0.005 & 0.096 & $-0.182^{*}$ \\
\hline & $(0.073)$ & $(0.083)$ & $(0.125)$ & $(0.100)$ \\
\hline \multirow[t]{2}{*}{ Female } & 0.047 & -0.035 & & \\
\hline & $(0.053)$ & $(0.024)$ & & \\
\hline \multirow[t]{2}{*}{ Mother's education } & $0.014^{*}$ & 0.011 & 0.018 & 0.015 \\
\hline & $(0.007)$ & $(0.010)$ & $(0.018)$ & $(0.011)$ \\
\hline \multirow[t]{2}{*}{$4^{\text {th }}$ grade } & $-0.205^{* *}$ & -0.178 & -0.338 & -0.080 \\
\hline & $(0.101)$ & $(0.143)$ & $(0.238)$ & $(0.150)$ \\
\hline \multirow[t]{2}{*}{ Single mother family } & -0.015 & -0.000 & -0.049 & 0.073 \\
\hline & $(0.051)$ & $(0.053)$ & $(0.074)$ & $(0.093)$ \\
\hline \multirow[t]{2}{*}{ Number of siblings } & $-0.061^{*}$ & $-0.070^{*}$ & -0.038 & $-0.085^{*}$ \\
\hline & $(0.033)$ & $(0.036)$ & $(0.049)$ & $(0.044)$ \\
\hline \multirow[t]{2}{*}{ Asset index } & $-0.200^{*}$ & -0.176 & -0.083 & -0.272 \\
\hline & $(0.122)$ & $(0.125)$ & $(0.155)$ & $(0.194)$ \\
\hline \multirow[t]{2}{*}{$\%$ female in class } & 0.065 & 0.178 & 0.704 & 0.031 \\
\hline & $(0.136)$ & $(0.205)$ & $(0.547)$ & $(0.163)$ \\
\hline \multirow[t]{2}{*}{ Average age in class } & $0.224^{*}$ & 0.204 & 0.267 & 0.185 \\
\hline & $(0.134)$ & $(0.188)$ & $(0.293)$ & $(0.168)$ \\
\hline \multirow[t]{2}{*}{ Average class size } & -0.006 & -0.007 & -0.031 & 0.002 \\
\hline & $(0.004)$ & $(0.007)$ & $(0.020)$ & $(0.004)$ \\
\hline \multirow[t]{2}{*}{ Mother works } & $-0.228^{* * *}$ & $-0.146^{*}$ & -0.204 & -0.118 \\
\hline & $(0.062)$ & $(0.076)$ & $(0.128)$ & $(0.082)$ \\
\hline \multirow[t]{2}{*}{ Father works } & 0.007 & 0.001 & 0.119 & -0.080 \\
\hline & $(0.098)$ & $(0.121)$ & $(0.140)$ & $(0.185)$ \\
\hline \multirow[t]{2}{*}{ Father white collar } & 0.022 & 0.021 & $-0.182^{*}$ & 0.103 \\
\hline & $(0.073)$ & $(0.085)$ & $(0.095)$ & $(0.098)$ \\
\hline Observations & 660 & 660 & 330 & 330 \\
\hline Number of clusters & 43 & 84 & 42 & 42 \\
\hline Hansen J statistic (p-value) & 0.910 & 0.865 & 0.618 & 0.684 \\
\hline $\begin{array}{l}\text { Weak identification Test: Kleibergen- } \\
\text { Paap statistic }\end{array}$ & 5.838 & 2.977 & 12.457 & 0.746 \\
\hline
\end{tabular}

Clustered standard errors in parenthesis; School/grade fixed effects included in all the estimations 
Table 6. Peer effects in risk aversion. GMM Continuously updated estimator (CUE) estimates. Robustness check.

\begin{tabular}{|c|c|c|c|c|}
\hline \multicolumn{5}{|c|}{ check. } \\
\hline & \multirow{2}{*}{$\begin{array}{l}\text { Peer group: } \\
\text { full class } \\
\text { Full sample } \\
(1)\end{array}$} & \multicolumn{3}{|c|}{ Peer group: same sex students in class } \\
\hline & & $\begin{array}{l}\text { Full sample } \\
\quad(2)\end{array}$ & $\begin{array}{l}\text { Males } \\
(3)\end{array}$ & $\begin{array}{c}\text { Females } \\
(4)\end{array}$ \\
\hline \multicolumn{5}{|l|}{$\begin{array}{l}\text { Robustness check I (alternative measure } \\
\text { of risk aversion) }\end{array}$} \\
\hline Peer group average risk aversion & $\begin{array}{c}1.145^{* * *} \\
(0.129)\end{array}$ & $\begin{array}{l}1.203^{* *} \\
(0.180)\end{array}$ & $\begin{array}{l}1.113^{* * *} \\
(0.203)\end{array}$ & $\begin{array}{c}0.322 \\
(0.436)\end{array}$ \\
\hline Anderson-Rubin F-test (p-value) & 0.000 & 0.020 & 0.000 & 0.404 \\
\hline Anderson-Rubin Chi-sq test ( $\mathrm{p}$-value) & 0.000 & 0.011 & 0.000 & 0.329 \\
\hline Hansen J statistic (p-value) & 0.705 & 0.847 & 0.648 & 0.210 \\
\hline $\begin{array}{l}\text { Weak identification Test: Kleibergen-Paap } \\
\text { statistic }\end{array}$ & 7.666 & 3.255 & 17.164 & 0.779 \\
\hline \multicolumn{5}{|l|}{$\begin{array}{c}\text { Robustness check II (median instead of } \\
\text { mean to measure peer variables) }\end{array}$} \\
\hline Peer group measure & $\begin{array}{c}0.799 * * * \\
(0.128)\end{array}$ & $\begin{array}{c}1.175^{* * *} \\
(0.250)\end{array}$ & $\begin{array}{l}0.917^{* * *} \\
(0.198)\end{array}$ & $\begin{array}{c}0.420 \\
(0.241)\end{array}$ \\
\hline Anderson-Rubin F-test (p-value) & 0.000 & 0.030 & 0.000 & 0.479 \\
\hline Anderson-Rubin Chi-sq test ( $p$-value) & 0.000 & 0.017 & 0.000 & 0.406 \\
\hline Hansen J statistic (p-value) & 0.264 & 0.843 & 0.244 & 0.319 \\
\hline $\begin{array}{l}\text { Weak identification Test: Kleibergen-Paap } \\
\text { statistic }\end{array}$ & 8.475 & 2.511 & 12.448 & 0.976 \\
\hline Observations & 660 & 660 & 330 & 330 \\
\hline Number of clusters & 43 & 84 & 42 & 42 \\
\hline \multicolumn{5}{|l|}{$\begin{array}{l}\text { Robustness check III (including extreme } \\
\text { values of the risk aversion coefficient) }\end{array}$} \\
\hline Peer group average risk aversion & $\begin{array}{c}0.962 \\
(0.338)\end{array}$ & $\begin{array}{c}0.917 \\
(0.319)\end{array}$ & $\begin{array}{l}1.088^{* *} \\
(0.276)\end{array}$ & $\begin{array}{c}0.902 \\
(0.301)\end{array}$ \\
\hline Anderson-Rubin F-test (p-value) & 0.607 & 0.689 & 0.040 & 0.933 \\
\hline Anderson-Rubin Chi-sq test ( $p$-value) & 0.574 & 0.668 & 0.017 & 0.924 \\
\hline Hansen J statistic ( $p$-value) & 0.187 & 0.241 & 0.165 & 0.925 \\
\hline $\begin{array}{l}\text { Weak identification Test: Kleibergen-Paap } \\
\text { statistic }\end{array}$ & 0.983 & 0.647 & 1.473 & 0.267 \\
\hline Observations & 873 & 873 & 427 & 446 \\
\hline Number of clusters & 43 & 86 & 43 & 43 \\
\hline
\end{tabular}

Clustered standard errors in parenthesis; School/grade fixed effects included in all the estimations Instruments - family background of the peer group: mother's education, mother's education squared, intact family structure and single mother.

* Significant at $10 \%$ level; ${ }^{* *}$ Significant at $5 \%$ level; ${ }^{* * *}$ Significant at $1 \%$ level. 
Figure 1

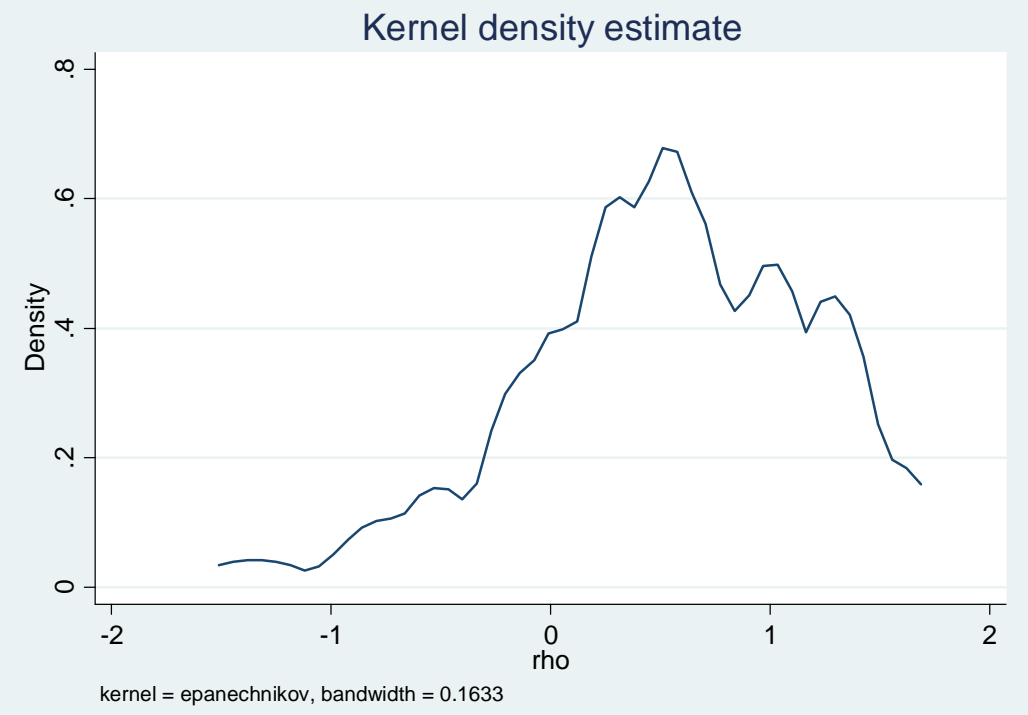


Documento de Investigación - ISSN 1688-6275 - No. 84 - 2012 - Balsa, A., Gandelman, N., González, N.

\section{Appendix}

\begin{tabular}{|c|c|c|c|}
\hline Student characteristics & 3rd grade & 4 th grade & Total \\
\hline Age & 27.395 & 38.148 & 65.543 \\
\hline Female & 8.610 & 5.927 & 14.537 \\
\hline Mother's education & 34.875 & 74.390 & 109.274 \\
\hline Single mother family & $21.761^{*}$ & 17.004 & $38.765^{*}$ \\
\hline Intact family structure & 18.298 & 19.392 & 37.690 \\
\hline Number of siblings & 49,692 & $82.586^{* *}$ & $132.278^{* *}$ \\
\hline Asset index & 8,318 & 19,566 & 27,884 \\
\hline Mother Works & 14.028 & 19.85 & 33.878 \\
\hline Father Works & 10.378 & 13.849 & 24.227 \\
\hline
\end{tabular}

* Significant at $10 \%$ level; ** Significant at $5 \%$ level; ${ }^{* * *}$ Significant at $1 \%$ level. 


\begin{tabular}{|c|c|c|c|}
\hline \multicolumn{4}{|c|}{ Table A.2. Summary statistics of characteristics. } \\
\hline Variables & $\begin{array}{l}\text { Analysis } \\
\text { sample (1) }\end{array}$ & $\begin{array}{c}\text { Excluded } \\
\text { sample (2) }\end{array}$ & $\begin{array}{l}\text { Difference } \\
(1)-(2)\end{array}$ \\
\hline Age & $\begin{array}{l}15.343 \\
(0.603)\end{array}$ & $\begin{array}{l}15.337 \\
(0.683)\end{array}$ & 0.005 \\
\hline Female & $\begin{array}{c}0.500 \\
(0.019)\end{array}$ & $\begin{array}{c}0.516 \\
(0.026)\end{array}$ & -0.016 \\
\hline Mother's education & $\begin{array}{l}14.920 \\
(2855)\end{array}$ & $\begin{array}{l}14.609 \\
(3.060)\end{array}$ & $0.310^{*}$ \\
\hline 4 th grade & $\begin{array}{c}0.536 \\
(0.499)\end{array}$ & $\begin{array}{c}0.456 \\
(0.499)\end{array}$ & $0.081^{* * *}$ \\
\hline Single mother family & $\begin{array}{c}0.209 \\
(0.407)\end{array}$ & $\begin{array}{c}0.206 \\
(0.405)\end{array}$ & 0.003 \\
\hline Complete family structure & $\begin{array}{c}0.697 \\
(0.460)\end{array}$ & $\begin{array}{c}0.688 \\
(0.464)\end{array}$ & 0.009 \\
\hline Number of siblings & $\begin{array}{l}1.150 \\
(0.832)\end{array}$ & $\begin{array}{c}1.204 \\
(0.901)\end{array}$ & -0.054 \\
\hline Asset index & $\begin{array}{c}0.488 \\
(0.255)\end{array}$ & $\begin{array}{c}0.501 \\
(0.278)\end{array}$ & -0.013 \\
\hline Average female in class & $\begin{array}{c}0.510 \\
(0.105)\end{array}$ & $\begin{array}{c}0.498 \\
(0.127)\end{array}$ & $0.013^{* *}$ \\
\hline Average age in class & $\begin{array}{l}15.368 \\
(0.477)\end{array}$ & $\begin{array}{l}15.297 \\
(0.505)\end{array}$ & $0.071^{* *}$ \\
\hline Average class size & $\begin{array}{l}23.536 \\
(4.951)\end{array}$ & $\begin{array}{l}22.719 \\
(4.568)\end{array}$ & $-0.818^{* * *}$ \\
\hline Mother works & $\begin{array}{c}0.845 \\
(0.362)\end{array}$ & $\begin{array}{c}0.836 \\
(0.371)\end{array}$ & 0.010 \\
\hline Father works & $\begin{array}{c}0.939 \\
(0.239)\end{array}$ & $\begin{array}{c}0.943 \\
(0.233)\end{array}$ & -0.003 \\
\hline Father white collar & $\begin{array}{c}0.755 \\
(0.431)\end{array}$ & $\begin{array}{c}0.708 \\
(0.455)\end{array}$ & $0.046^{*}$ \\
\hline $\begin{array}{c}\text { Frequency of alcohol } \\
\text { consumption last } 30 \text { days }\end{array}$ & $\begin{array}{c}1.924 \\
(2.549)\end{array}$ & $\begin{array}{c}2.079 \\
(3.445)\end{array}$ & -0.154 \\
\hline $\begin{array}{l}\text { Frequency of cigarettes } \\
\text { consumption last } 30 \text { day }\end{array}$ & $\begin{array}{c}2.045 \\
(6.351)\end{array}$ & $\begin{array}{c}2.557 \\
(7.329)\end{array}$ & -0.512 \\
\hline $\begin{array}{l}\text { Frequency of marihuana } \\
\text { consumption last } 3 \text { months }\end{array}$ & $\begin{array}{c}1.182 \\
(6.725)\end{array}$ & $\begin{array}{c}1.746 \\
(8.398)\end{array}$ & -0.564 \\
\hline Observations & 660 & 384 & \\
\hline
\end{tabular}

Note 1: Standard deviation in parenthesis

Note 2: Excluded observation are those students who: 1) belong to the two school that have only one class in each grade; 2 ) choose always option A or B (extreme values); 3 ) switch back and forth between A and B (illogic answers); and 4) do not answer one of the relevant questions for the analysis.

* Significant at $10 \%$ level; ** Significant at $5 \%$ level; *** Significant at $1 \%$ level. 
Table A3. Peer effects in substance use. First stage estimates of Table 5.

Dependent variable - Peer group measure of:

\begin{tabular}{|c|c|c|c|c|}
\hline & \multirow{2}{*}{$\begin{array}{c}\text { Peer } \\
\text { group: full } \\
\text { class } \\
\text { Full } \\
\text { sample } \\
(1)\end{array}$} & \multicolumn{3}{|c|}{$\begin{array}{c}\text { Peer group: same sex students in } \\
\text { class }\end{array}$} \\
\hline & & $\begin{array}{l}\text { Full } \\
\text { sample } \\
(2)\end{array}$ & $\begin{array}{l}\text { Males } \\
\text { (3) }\end{array}$ & $\begin{array}{c}\text { Females } \\
(4)\end{array}$ \\
\hline \multicolumn{5}{|l|}{ Excluded Instruments: } \\
\hline Mother's education & $\begin{array}{c}-0.752^{* *} \\
(0.372)\end{array}$ & $\begin{array}{c}-0.653 \\
(0.710)\end{array}$ & $\begin{array}{c}-0.784^{* *} \\
(0.378)\end{array}$ & $\begin{array}{c}-0.845 \\
(0.835)\end{array}$ \\
\hline Mother's education squared & $\begin{array}{r}0.025^{*} \\
(0.013)\end{array}$ & $\begin{array}{r}0.021 \\
(0.024)\end{array}$ & $\begin{array}{c}0.026^{*} \\
(0.013)\end{array}$ & $\begin{array}{r}0.030 \\
(0.030)\end{array}$ \\
\hline Intact family structure & $\begin{array}{c}-1.135^{* * *} \\
(0.356)\end{array}$ & $\begin{array}{c}-1.212^{* * *} \\
(0.397)\end{array}$ & $\begin{array}{c}-1.972^{* * *} \\
(0.372)\end{array}$ & $\begin{array}{r}-0.451 \\
(0.508)\end{array}$ \\
\hline Single mother family & $\begin{array}{l}-1.041^{* *} \\
(0.398)\end{array}$ & $\begin{array}{l}-1.156^{* *} \\
(0.456)\end{array}$ & $\begin{array}{c}-2.232^{* * *} \\
(0.376)\end{array}$ & $\begin{array}{r}-0.364 \\
(0.683)\end{array}$ \\
\hline Father Works & $\begin{array}{r}0.040 \\
(0.315)\end{array}$ & $\begin{array}{r}-0.048 \\
(0.417)\end{array}$ & $\begin{array}{c}-0.671 \\
(0.750)\end{array}$ & $\begin{array}{r}-0.153 \\
(0.441)\end{array}$ \\
\hline Observations & 660 & 660 & 330 & 330 \\
\hline Number of clusters & 43 & 84 & 42 & 42 \\
\hline
\end{tabular}

${ }^{*}$ Significant at $10 \%$ level; ${ }^{* *}$ Significant at $5 \%$ level; ${ }^{* * *}$ Significant at $1 \%$ level. 